\title{
Amentoflavone protects against high fat-induced metabolic dysfunction: Possible role of the regulation of adipogenic differentiation
}

\author{
GUANGYONG CHEN ${ }^{1 *}$, YANGDONG HAN ${ }^{2 *}$, WANG HE ${ }^{2}$ and FENG LIANG ${ }^{3}$ \\ ${ }^{1}$ Department of Pathology, Beijing Friendship Hospital, Capital Medical University, Beijing 100050; \\ ${ }^{2}$ Department of Endocrinology, Xi'an No. 1 Hospital, Xi'an, Shaanxi 710002; ${ }^{3}$ Affiliated Hospital of \\ the Chinese Academy of Military Medical Sciences, Beijing 100071, P.R. China
}

Received December 29, 2015; Accepted September 22, 2016

DOI: $10.3892 /$ ijmm.2016.2772

\begin{abstract}
In the present study, we evaluated the protective effects of amentoflavone (AMF) against high-fat (HF) diet-induced metabolic dysfunction and focused on the influence of AMF on adipogenic differentiation during 3T3-L1 adipocyte differentiation. For this purpose, male Wistar rats were fed a HF diet or a HF diet with AMF (10 or $50 \mathrm{mg} / \mathrm{kg}$ ). We found that AMF protected against HF diet-induced metabolic dysfunction in a dose-dependent manner, as evidenced by a decrease in the fasting blood glucose levels, fasting insulin levels and the homeostatic model assessment-insulin resistance index (HOMA-IR), as well as by a decrease in the glucose level, as shown by the intraperitoneal glucose tolerance test and intraperitoneal insulin tolerance test. Moreover, the results revealed that AMF significantly inhibited the increase in body weight, the weight of perirenal adipose tissues and the serum triglyceride (TG) content of the rats fed the HF diet in a dose-dependent manner. AMF also inhibited the accumulation of oil droplets in differentiated 3T3-L1 adipocytes in a concentration-dependent manner. The incubation of the cells with AMF for 0-8, 0-2, 2-4, or 4-8 days markedly inhibited adipogenesis. During the early phase of the adipocyte differentiation of 3T3-L1 cells, AMF decreased CCAAT/enhancer-binding protein (C/EBP) $\beta$ expression in a concentration-dependent manner, leading to the inhibition of mitotic clonal expansion (MCE). Moreover, our results demonstrated that AMF significantly increased reactive oxygen species (ROS) generation in the cells and the antioxidant, N-acetylcysteine (NAC), mark-
\end{abstract}

Correspondence to: Dr Feng Liang, Affiliated Hospital of the Chinese Academy of Military Medical Sciences, Dongda Street 8, Beijing 100071, P.R. China

E-mail: feng_liang1212@126.com

*Contributed equally

Key words: amentoflavone, metabolic dysfunction, adipocyte differentiation, CCAAT/enhancer-binding protein, peroxisome proliferator-activated receptor $\gamma$ edly attenuated the inhibitory effects of AMF on adipogenesis. AMF also inhibited the expression of peroxisome proliferatoractivated receptor $\gamma(\mathrm{PPAR} \gamma)$ and C/EBP $\alpha$ and the expression of downstream targets in a concentration-dependent manner. The overexpression of PPAR $\gamma$ and $\mathrm{C} / \mathrm{EBP} \alpha$ (by transfection with respective overexpression plasmids) attentuated the inhibitory effects of AMF on the formation of oil droplets. The inhibitory effects of AMF on adipocyte differentiation may contribute to its protective effects against HF diet-induced metabolic dysfunction. Overall, the data in our study provide novel insight into the mechanisms responsible for the protective effects of AMF against HF diet-induced metabolic dysfunction and those for its inhibitory effect on adipocyte differentiation.

\section{Introduction}

Type 2 diabetes and metabolic syndrome are prevalent worldwide (1). These metabolic disorders are characterized by the disruption of glucose and lipid metabolism. Obesity is major risk for the development of type 2 diabetes and related metabolic disorders (2). The prevalence of obesity has increased worldwide, with more than a billion adults being overweight and over 300 million adults being classified as obese (3). Obesity is defined not as an excess of body weight, but as an excessive accumulation of fat mass in white adipose tissue to the extent that health may be adversely affected.

The accumulation of body fat greatly depends on adipocyte differentiation, also known as adipogenic differentiation or adipogenesis (4). Adipocyte differentiation is a complex process which is divided into four steps, including initial growth arrest, mitotic clonal expansion (MCE), early differentiation and terminal differentiation, namely the development of the mature adipocyte phenotype $(5,6)$. Adipocyte differentiation is regulated by a series of signaling pathways triggered by an adipogenic stimulus. Among these factors, peroxisome proliferator-activated receptor $\gamma(\mathrm{PPAR} \gamma)$ and CCAAT/enhancer-binding protein $(\mathrm{C} /$ EBP) $\alpha$ family members are the key transcription factors responsible for adipogenesis $(7,8)$. In response to adipogenic stimuli, $\mathrm{C} / \mathrm{EBP} \beta$ is rapidly activated and functions at the early stage of differentiation by initiating the MCE of pre-adipocytes and activating the PPAR $\gamma$ and C/EBP $\alpha$ regulatory network (9-12). C/ 
EBP $\alpha$ and PPAR $\gamma$ mutually interact and form a positive feedback loop that plays pivotal roles during the later stage of adipocyte differentiation by inducing and maintaining the expression of multiple adipocyte-specific genes, i.e. fatty-acid binding protein (aP2), cluster of differentiation 36 (CD36, a receptor for lipoproteins) and fatty acid transport protein-1 (FATP-1) (13-16). Abnormal adipocyte differentiation is involved in the development of multiple metabolic disorders.

Over the past years, many researchers have focused on the investigation of dietary agents and natural products that can be used for the intervention of metabolic disorders. Amentoflavone (AMF) is a polyphenolic compound derived from the extracts of Selaginella tamariscina which has been found to possess potent anti-inflammatory effects (17-20). A previous study demonstrated that AMF inhibits protein tyrosine phosphatase $1 \mathrm{~B}$ activity, which has been proposed as a strategy for the treatment of type 2 diabetes and obesity (21). The present study was designed to examine the effects of AMF on high fat (HF) diet-induced metabolic dysfunction, focusing on the regulation of adipocyte differentiation.

\section{Materials and methods}

Materials. Anti- $\beta$-actin (sc-130656), anti-PPAR $\gamma$ (sc-7273), anti-C/EBP $\alpha$ (sc-61) and anti-C/EBP $\beta$ (sc-746) antibodies and 3-isobutyl-1-methylxanthine (IBMX) were purchased from Santa Cruz Biotechnology, Inc. (Santa Cruz, CA, USA). AMF, Oil Red O, insulin, 2',7'-dichlorodihydrofluorescein diacetate (DCFH-DA), N-acetylcysteine (NAC) and most of the chemicals and reagents used in this study were procured from Sigma (St. Louis, MO, USA).

Animal experiments. All animal experiments were performed according to the procedures approved by the Affiliated Hospital of the Chinese Academy of Military Medical Sciences, Beijing, China (approval no. CAMS-2014-12-115). A total of 32 male Wistar rats (6-8 weeks old; weighing 180-220 g) were purchased from the Animal Centre of Capital Medical University, Beijing, China. The rats were housed under controlled temperature $\left(23 \pm 2^{\circ} \mathrm{C}\right)$ and humidity $(55 \pm 5 \%)$ conditions with a standard light and dark ( $12 \mathrm{~h}$ light/dark) cycle. The rats were randomly divided into 4 groups as follows: the control group, the $\mathrm{HF}$ diet group, the $\mathrm{HF}$ diet $+10 \mathrm{mg} / \mathrm{kg} \mathrm{AMF}$ group and the $\mathrm{HF}$ diet $+50 \mathrm{mg} / \mathrm{kg}$ AMF group. The rats in the control group were fed a standard diet (22\% protein, $63 \%$ carbohydrate and 5\% fat; Animal Center of Chinese Academy of Medical Sciences). The rats in the HF diet group were given a HF diet. The HF diet consisted of $10 \%$ protein, $72 \%$ carbohydrate and $8 \%$ fat; (Animal Center of Chinese Academy of Medical Sciences). Rats in $\mathrm{HF}$ diet + AMF group were administrated with 10 or $50 \mathrm{mg} /$ $\mathrm{kg}$ /day AMF via intraperitoneal injection (AMF was dissolved in DMSO and diluted in saline) for 4 months. The experimental period lasted for 4 months. After being fed the different diets, fasting blood glucose (FBG) levels (12 h) were measured. At the end of the experiment, the rats were weighed using a scale used for animals prior to anesthesia. The mice were anesthetized with sodium pentobarbital, perirenal adipose tissues were weighed (perirenal adipose tissues were cut using surgical scissors and weighed using a precision balance) and tissue and blood samples (obtained from the vena cava) were then harvested for the assays.
Intraperitoneal glucose tolerance test (IPGTT) and intraperitoneal insulin tolerance test (IPITT). After the animals were fed the different diets, the IPGTT and the IPITT were performed as previously described (22). The rats were fasted for 12 and $4 \mathrm{~h}$, respectively, and the blood samples were obtained from the tail vein for the detection of basal glucose levels. Subsequently, each rat was intraperitoneally injected with glucose $(1 \mathrm{~g} / \mathrm{kg}$ body weight $)$, or insulin $(0.75 \mathrm{U} / \mathrm{kg}$ body weight). Blood samples were obtained from the tail vein at 30 , 60 and $120 \mathrm{~min}$ after the injection and were analyzed immediately for the glucose concentration. The area under curve (AUC) was calculated to determine the relative efficiency of AMF. In the IPGTT and IPITT tests, AUC was used to evaluate response to glucose and insulin load. AUC was calculated as: (glucose level at $0 \mathrm{~min}+$ glucose level at $30 \mathrm{~min}) \times 0.5 / 2+$ (glucose level at $30 \mathrm{~min}+$ glucose level at $60 \mathrm{~min}$ ) $\mathrm{x} 0.5 / 2+$ (glucose level at $60 \mathrm{~min}+$ glucose level at $120 \mathrm{~min}$ ) $\times 1 / 2$.

Biochemical analysis. After being fed the different diets, the blood samples were harvested and serum was separated for the estimation of triglyceride (TG) levels (Nanjing Jiancheng Co., Nanjing, China) and insulin levels (Crystal Chem, Downers Grove, IL, USA) using commercial kits. The assays were conducted according to the manufacture's instructions. The TG content was determined according to the formation of quinonyl compounds and the absorbance at $510 \mathrm{~nm}$ was measured. Insulin was determined with the ultra-sensitive rat insulin ELISA kit. At the end of detection, the A450 and subtract A630 values were measured within $30 \mathrm{~min}$ and insulin concentrations were calculated using the standard curve. Homeostatic model assessment-insulin resistance index (HOMA-IR) is an index reflecting the insulin sensitivity. HOMA-IR was calculated as: (glucose level x insulin level)/22.5.

Cell culture and treatment. The 3T3-L1 pre-adipocytes were cultured and differentiation was induced as previously described (23). The 3T3-L1 pre-adipocytes were cultured in Dulbecco's modified Eagle's medium (DMEM) supplemented with $10 \%$ bovine calf serum, penicillin $(100 \mathrm{U} / \mathrm{ml})$, streptomycin $(100 \mu \mathrm{g} / \mathrm{ml})$ and glutamine $(292 \mu \mathrm{g} / \mathrm{l})$. The cells were maintained at $37^{\circ} \mathrm{C}$ in a humidified $5 \% \mathrm{CO}_{2}$ atmosphere. AT 2 days post-confluence (day 0 ), the $3 \mathrm{~T} 3-\mathrm{L} 1$ pre-adipocytes were stimulated with $0.5 \mathrm{mM}$ IBMX, $1 \mu \mathrm{M}$ dexamethasone and $167 \mathrm{nM}$ insulin in DMEM containing 10\% fetal bovine serum (FBS) (also known as DMI differentiation induction medium) for 2 days (day 2). The cells were then incubated with $10 \% \mathrm{FBS} / \mathrm{DMEM}$ medium with $167 \mathrm{nM}$ insulin for a further 2 days (day 4 ) and were then cultured in $10 \%$ FBS/DMEM medium for an additional 4 days (day 8). Following 8 days of differentiation, $>90 \%$ of the cells became mature adipocytes with lipid-filled droplets. For AMF treatment, indicated concentrations (1-10 $\mu \mathrm{g} / \mathrm{ml})$ of AMF were added to the DMI induction medium for the indicated incubation time periods ( 2 days) maintained when the medium was changed.

Cell transfection. The scramble plasmids, and the $\mathrm{C} /$ $\mathrm{EBP} \alpha$ and PPAR $\gamma$ plasmids were synthesized (GeneChem, Shanghai, China). Transient transfection was performed using Lipofectamine 2000 (Invitrogen, Carlsbad, CA, USA) according to the manufacturer's instructions. $\mathrm{C} / \mathrm{EBP} \alpha(500 \mathrm{ng})$, 
or PPAR $\gamma(500 \mathrm{ng})$ or their empty vectors were mixed with $4 \mu 1$ Lipofectamine 2000 (Invitrogen) in $400 \mu 1$ serum-free medium and placed at temperature for $20 \mathrm{~min}$. The mixture was then added to the wells and incubated for 4-6 h. The medium was then changed to complete culture medium. The cells were transfected with the plasmids 2 days before confluence.

Determination of lipid accumulation. After the treatments, the adipocytes were fixed with $4 \%$ paraformaldehyde for $30 \mathrm{~min}$ and rinsed with water. Subsequently, the fixed cells were stained with Oil Red O staining solution (6 parts of saturated Oil Red O dye in isopropanol +4 parts water) for $30 \mathrm{~min}$. The cells were washed with water to remove the excess dye. Lipid accumulation in the cells was observed under a microscope (Olympus, Tokyo, Japan). The cells were then incubated with $4 \%$ Nonidet P-40 in isopropanol for $5 \mathrm{~min}$ to dissolve the stained oil droplets. The absorbance of the dye lipid complex was measured at $510 \mathrm{~nm}$ using a plate reader (Tecan, Männedorf, Switzerland).

Cell viability and proliferation. Cell viability was examined by 3-(4,5-dimethylthiazol-2-yl)-2,5-diphenyltetrazolium bromide (MTT) assay. A total of $0.5 \mathrm{mg} / \mathrm{ml}$ MTT was added to each well and incubated for $4 \mathrm{~h}$. After aspiration of the supernatants, formazan crystals were dissolved using DMSO. The absorbance at $550 \mathrm{~nm}$ was measured using a plate reader (Tecan). Cell proliferation was determined using a CCK8 assay kit (Beyotime, Shanghai, China) according to the manufacturer's instructions. Cells were plated in 96-well culture plates. After the treatment, $10 \mu \mathrm{l}$ of the CCK- 8 solution was added to each well and cells were cultured at $37^{\circ} \mathrm{C}$ for an additional hour. The absorbance at $450 \mathrm{~nm}$ was measured to evaluate cell proliferation (Tecan). The absorbance was detected at 570 and $450 \mathrm{~nm}$, respectively, using a microplate reader (Bio-Rad Biosystems, Hercules, CA, USA).

Determination of reactive oxygen species (ROS) generation. ROS were detected usng the specific probe, DCFH-DA, as previously described (24). After the treatments, the cells were incubated with $10 \mu \mathrm{M}$ DCFH-DA in the dark at $37^{\circ} \mathrm{C}$ for $30 \mathrm{~min}$. After washing twice with PBS, the ROS levels were analyzed by flow cytometry (C6; BD Biosciences, San Jose, CA, USA).

RNA isolation and reverse transcription-quantitative $P C R$ (RT-qPCR). Total RNA was isolated from the cells using an RNA isolation kit (Tiangen, Beijing, China) according to the manufacturer's instructions. RNA (500 ng) was reverse transcribed into cDNA using the First Strand cDNA synthesis kit (Takara, Tokyo, Japan). Quantitative PCR (qPCR) was performed using SYBR-Green (Takara) in a real-time PCR system from Bio-Rad Biosystems. The primers used were as follows: PPAR $\gamma$ forward, 5'-ACA AGA GCT GAC CCA ATG-3'and reverse, 5'-CAT GAG GGA GTT AGA AGG-3'; aP2 forward, 5'-CGT TCT CTT TCT CCC TGT-3' and reverse, 5'-TTG AAG GAA ATC TCG GTG-3'; CD36 forward, 5'-TTT GGA TCT TTG ATG TGC-3' and reverse, 5'-TTT CCT TGG CTA GAT AAC-3'; C/EBP $\alpha$ forward, 5'-AGGTGCTGGAGTTGACCAGT-3' and reverse, 5'-CAGCCTAGAGATCCAGCGAC-3'; $\beta$-actin forward, 5'-AGG CCA ACC GTG AAA AGA TG-3' and reverse, 5'-TGG CGT GAG GGA GAG CAT AG-3'. The $2^{-\Delta \Delta C T}$ method was used
Table I. Effect of AMF on high fat diet-induced metabolic dysfunction.

\begin{tabular}{lccc}
\hline Group & FBG $(\mathrm{mg} / \mathrm{dl})$ & FI $(\mathrm{ng} / \mathrm{dl})$ & HOMA-IR \\
\hline Control & $65.9 \pm 6.3$ & $1.5 \pm 0.4$ & $0.5 \pm 0.2$ \\
High-fat diet & $118.5 \pm 12.8^{\mathrm{a}}$ & $4.3 \pm 0.6^{\mathrm{a}}$ & $8.6 \pm 2.7^{\mathrm{a}}$ \\
$10 \mathrm{mg} / \mathrm{kg} \mathrm{AMF}$ & $101.1 \pm 9.7^{\mathrm{b}}$ & $3.2 \pm 0.5^{\mathrm{b}}$ & $5.7 \pm 1.1^{\mathrm{b}}$ \\
$50 \mathrm{mg} / \mathrm{kg} \mathrm{AMF}$ & $82.9 \pm 8.1^{\mathrm{b}}$ & $2.8 \pm 0.4^{\mathrm{b}}$ & $3.2 \pm 2.3^{\mathrm{b}}$ \\
\hline
\end{tabular}

${ }^{\mathrm{a}} \mathrm{p}<0.05$ compared with the control group; ${ }^{\mathrm{b}} \mathrm{p}<0.05$ compared with the high-fat diet group. AMF, amentoflavone; FBG, fasting blood glucose levels; FI, fasting insulin levels.

to measure gene expression compared with the endogenous control ( $\beta$-actin). Amplification was performed with an initial step at $94^{\circ} \mathrm{C}$ for $5 \mathrm{~min}$, followed by 40 cycles of denaturation at $94^{\circ} \mathrm{C}$ for $30 \mathrm{sec}$, annealing at $63^{\circ} \mathrm{C}$ for $30 \mathrm{sec}$, and then extension at $72^{\circ} \mathrm{C}$ for $10 \mathrm{sec}$.

Protein extraction and western blot analysis. Total protein was extracted from the cells using RIPA lysis buffer according to the manufacturer's instructions. The cell lysates were washed with cold phosphate-buffered saline (PBS) and incubated on ice in lysis buffer for $30 \mathrm{~min}$. The lysates were centrifuged at $20,000 \mathrm{x} \mathrm{g}$ for $30 \mathrm{~min}$ at $4^{\circ} \mathrm{C}$ and the protein concentrations in the supernatants were measured using a Bradford protein assay kit (Pierce, Rockford, IL, USA). Approximately $20 \mu \mathrm{g}$ of protein was separated by sodium dodecyl sulfate-polyacrylamide gel electrophoresis (SDS-PAGE). The proteins were then transferred onto PVDF membranes (Millipore, Billerica, MA, USA), and the membranes were then blocked with $8 \%$ non-fat milk. The membranes were incubated overnight at $4^{\circ} \mathrm{C}$ with the primary antibodies (anti- $\beta$-actin, anti-PPAR $\gamma$, anti-C/EBP $\alpha$ and anti-C/EBP $\beta$ antibodies). After washing with TBST, the membranes was incubated with a horseradish peroxidaseconjugated secondary antibody (Cat. no. 32260; Pierce) at $37^{\circ} \mathrm{C}$ for $30 \mathrm{~min}$. Protein bands were visualized by ECL and captured using a Bio-Rad Imaging System (Bio-Rad Biosystems).

Statistical analysis. Results were expressed as the means \pm SEM. Statistical analysis was carried out by one-way analysis of variance (ANOVA) followed by the Newmane Keuls multiplecomparison post hoc test using GraphPad Prism software. Data were considered statistically significant for $\mathrm{p}<0.05$.

\section{Results}

AMF attenuates metabolic dysfunction in rats fed a HF diet. In the present study, we first evaluated the effects of AMF on metabolic dysfunction in rats fed a HF diet. As shown in Table I, the FBG levels in the HF diet group were $118.5 \pm 12.8 \mathrm{mg} / \mathrm{dl}$, which were significantly higher than those of the control group rats $(65.9 \pm 6.3 \mathrm{mg} / \mathrm{dl})$. The administration of $\mathrm{AMF}$ at 10 and $50 \mathrm{mg} / \mathrm{kg}$ significantly decreased the FBG levels to $101.1 \pm 9.7$ and $82.9 \pm 8.1 \mathrm{mg} / \mathrm{dl}$, respectively in the HF diet group rats. The HF diet markedly increased the fasting insulin levels from $1.5 \pm 0.4$ (control group) to $4.3 \pm 0.6 \mathrm{ng} / \mathrm{dl}$. The administration 
Table II. Effect of AMF on high-fat diet-induced glucose and insulin intolerance.

\begin{tabular}{|c|c|c|c|c|c|}
\hline \multirow[b]{2}{*}{ Group } & \multicolumn{5}{|c|}{ IPGTT (mg/dl) } \\
\hline & $0 \mathrm{~min}$ & $30 \mathrm{~min}$ & $60 \mathrm{~min}$ & $120 \mathrm{~min}$ & AUC \\
\hline Control & $64.8 \pm 4.6$ & $118.2 \pm 5.8$ & $97.1 \pm 6.3$ & $77.4 \pm 5.5$ & $191 \pm 16$ \\
\hline High-fat diet & $128.1 \pm 5.1^{\mathrm{a}}$ & $183.3 \pm 5.4^{\mathrm{a}}$ & $165.2 \pm 6.6^{\mathrm{a}}$ & $145.8 \pm 6.7^{\mathrm{a}}$ & $319 \pm 23^{\mathrm{a}}$ \\
\hline $10 \mathrm{mg} / \mathrm{kg} \mathrm{AMF}$ & $105.2 \pm 4.9^{\mathrm{b}}$ & $163.8 \pm 4.8^{b}$ & $145.6 \pm 5.3^{\mathrm{b}}$ & $129.9 \pm 6.4^{\mathrm{b}}$ & $285 \pm 18^{b}$ \\
\hline \multirow[t]{2}{*}{$50 \mathrm{mg} / \mathrm{kg}$ AMF } & $87.8 \pm 5.1^{\mathrm{b}}$ & $131.9 \pm 5.2^{\mathrm{b}}$ & $127.5 \pm 5.7^{\mathrm{b}}$ & $116.5 \pm 6.6^{\mathrm{b}}$ & $247 \pm 22^{b}$ \\
\hline & \multicolumn{5}{|c|}{ IPITT (mg/dl) } \\
\hline Control & $77.18 \pm 5.2$ & $51.3 \pm 5.3$ & $43.1 \pm 4.9$ & $44.7 \pm 5.4$ & $121 \pm 8$ \\
\hline High-fat diet & $154.8 \pm 5.1^{\mathrm{a}}$ & $97.9 \pm 6.6^{\mathrm{a}}$ & $85.6 \pm 5.8^{\mathrm{a}}$ & $92.4 \pm 5.7^{\mathrm{a}}$ & $209 \pm 9^{a}$ \\
\hline $10 \mathrm{mg} / \mathrm{kg} \mathrm{AMF}$ & $125.6 \pm 5.4^{\mathrm{b}}$ & $79.5 \pm 4.7^{\mathrm{b}}$ & $68.9 \pm 5.6^{\mathrm{b}}$ & $75.8 \pm 5.1^{\mathrm{b}}$ & $184 \pm 7^{b}$ \\
\hline $50 \mathrm{mg} / \mathrm{kg} \mathrm{AMF}$ & $91.7 \pm 4.8^{\mathrm{b}}$ & $61.6 \pm 5.2^{\mathrm{b}}$ & $53.9 \pm 5.7^{\mathrm{b}}$ & $57.8 \pm 5.5^{\mathrm{b}}$ & $149 \pm 8^{b}$ \\
\hline
\end{tabular}

${ }^{\mathrm{a}} \mathrm{p}<0.05$ compared with the control group; ${ }^{\mathrm{b}} \mathrm{p}<0.05$ compared with the high-fat diet group; AMF, amentoflavone; IPGTT, intraperitoneal glucose tolerance test; IPITT, intraperitoneal insulin tolerance test; AUC, area under the curve.

Table III. Effect of AMF on high fat diet-induced lipid accumulation.

\begin{tabular}{lccc}
\hline Group & BW (g) & PATW $(\mathrm{g})$ & Serum TG (mg/dl) \\
\hline Control & $362 \pm 38$ & $3.5 \pm 1.4$ & $146 \pm 21$ \\
High fat & $484 \pm 37^{\mathrm{a}}$ & $13.8 \pm 3.9^{\mathrm{a}}$ & $249 \pm 25^{\mathrm{a}}$ \\
$10 \mathrm{mg} / \mathrm{kg} \mathrm{AMF}$ & $434 \pm 29^{\mathrm{b}}$ & $10.2 \pm 1.6^{\mathrm{b}}$ & $211 \pm 15^{\mathrm{b}}$ \\
$50 \mathrm{mg} / \mathrm{kg} \mathrm{AMF}$ & $402 \pm 25^{\mathrm{b}}$ & $8.3 \pm 2.5^{\mathrm{b}}$ & $176 \pm 14^{\mathrm{b}}$ \\
\hline
\end{tabular}

${ }^{\mathrm{a}} \mathrm{p}<0.05$ compared with the control group; ${ }^{\mathrm{b}} \mathrm{p}<0.05$ compared with the high-fat diet group. AMF, amentoflavone; BW, body weight; PATW, perirenal adipose tissue weight; TG, triglyceride.

of 10 and $50 \mathrm{mg} / \mathrm{kg}$ AMF significantly decreased the fasting insulin levels to $3.2 \pm 0.5$ and $2.8 \pm 0.4 \mathrm{ng} / \mathrm{dl}$, respectively in the HF diet-fed rats. As also shown in Table I, the HOMA-IR value was increased from $0.5 \pm 0.2$ to $8.6 \pm 2.7$ in the rats fed the $\mathrm{HF}$ diet. The administration of 10 and $50 \mathrm{mg} / \mathrm{kg}$ AMF significantly inhibited the increase in the HOMA-IR value $(5.7 \pm 1.1$ and 3.2 \pm 2.3 , respectively) in the HF diet-fed rats.

We also examined the effects of AMF on glucose and insulin tolerance in the HF diet-fed rats (Table II). In the HF diet group, following the injection of glucose, the glucose level increased from $128.1 \pm 5.1$ to $183.3 \pm 5.4 \mathrm{mg} / \mathrm{dl}$ at $30 \mathrm{~min}$ and then decreased to $145.8 \pm 6.7 \mathrm{mg} / \mathrm{dl}$ at $120 \mathrm{~min}$, which was significantly higher than that of the control group. In the $10 \mathrm{mg} /$ $\mathrm{kg}$ AMF group, following the injection of glucose, the glucose level increased from $105.2 \pm 4.9$ to $163.8 \pm 4.8 \mathrm{mg} / \mathrm{dl}$ at $30 \mathrm{~min}$ at $30 \mathrm{~min}$ and then decreased to $129.9 \pm 6.4 \mathrm{mg} / \mathrm{dl}$ at $120 \mathrm{~min}$. In the $50 \mathrm{mg} / \mathrm{kg}$ AMF group, following the injection of glucose, the glucose level increased from $87.8 \pm 5.1$ to $131.9 \pm 5.2 \mathrm{mg} / \mathrm{dl}$ at $30 \mathrm{~min}$ and then decreased to $116.5 \pm 6.6 \mathrm{mg} / \mathrm{dl}$ at $120 \mathrm{~min}$. The glucose levels in the AMF groups were significantly lower than those of the HF-diet group, as indicated by the IPGTT. The AUC was calculated and the results revealed that AMF significantly inhibited the increase in the AUC value in the HF diet-fed rats, as indicated by the IPGTT.

As regards insulin tolerance, in the HF-diet group, following the injection of insulin, the glucose level decreased from $154.8 \pm 5.1$ to $85.6 \pm 5.8 \mathrm{mg} / \mathrm{dl}$ at $60 \mathrm{~min}$ and then increased to $92.4 \pm 5.7 \mathrm{mg} / \mathrm{dl}$ at $120 \mathrm{~min}$, which was significantly higher than that of the control group. In the $10 \mathrm{mg} / \mathrm{kg}$ AMF group, following the injection of insulin, the glucose level decreased from $125.6 \pm 5.4$ to $68.9 \pm 5.6 \mathrm{mg} / \mathrm{dl}$ at $60 \mathrm{~min}$ and then increased to $75.8 \pm 5.1 \mathrm{mg} / \mathrm{dl}$ at $120 \mathrm{~min}$. In the $50 \mathrm{mg} / \mathrm{kg}$ AMF group, following the injection of insulin, the glucose level decreased from $91.7 \pm 4.8$ to $53.9 \pm 5.7 \mathrm{mg} / \mathrm{dl}$ at $60 \mathrm{~min}$ and then increased to $57.8 \pm 5.5 \mathrm{mg} / \mathrm{dl}$ at $120 \mathrm{~min}$. The glucose levels in the AMF groups were significantly lower than those of the HF diet group, as indicated by IPITT. As shown by the AUC values, AMF significantly inhibited the increase in the AUC values in the HF diet-fed rats, as indicated by the IPITT. These results indicated that the administration of AMF significantly attenuated HF diet-induced metabolic dysfunction in rats.

AMF attenuates lipid accumulation in rats fed a HF diet. A shown in Table III, the HF diet significantly increased the body weights of the rats from $362 \pm 38$ to $484 \pm 37 \mathrm{~g}$. The administration of 10 and $50 \mathrm{mg} / \mathrm{kg}$ AMF significantly inhibited the HF diet-induced increase in body weight $(434 \pm 29$ and $402 \pm 25$, respectively). We also determined the weights of perirenal adipose tissues and the results revealed that the weights of the perirenal adipose tissues were significantly increased in the HF diet group $(13.8 \pm 3.9 \mathrm{~g})$. The administration of 10 and $50 \mathrm{mg} / \mathrm{kg}$ AMF markedly decreased the weights of the perirenal adipose tissues to $10.2 \pm 1.6$ and $8.3 \pm 2.5 \mathrm{~g}$, respectively, in the HF diet-fed rats (Table III). The serum TG content was also determined. As shown in Table III, the HF diet induced a significant increase in the TG content $(249 \pm 25 \mathrm{mg} / \mathrm{dl})$. The administration of 10 and $50 \mathrm{mg} / \mathrm{kg}$ AMF significantly inhibited the increase in the serum TG content $(211 \pm 15$ and $176 \pm 14$, respectively) in the rats fed the HF diet. These results indi- 

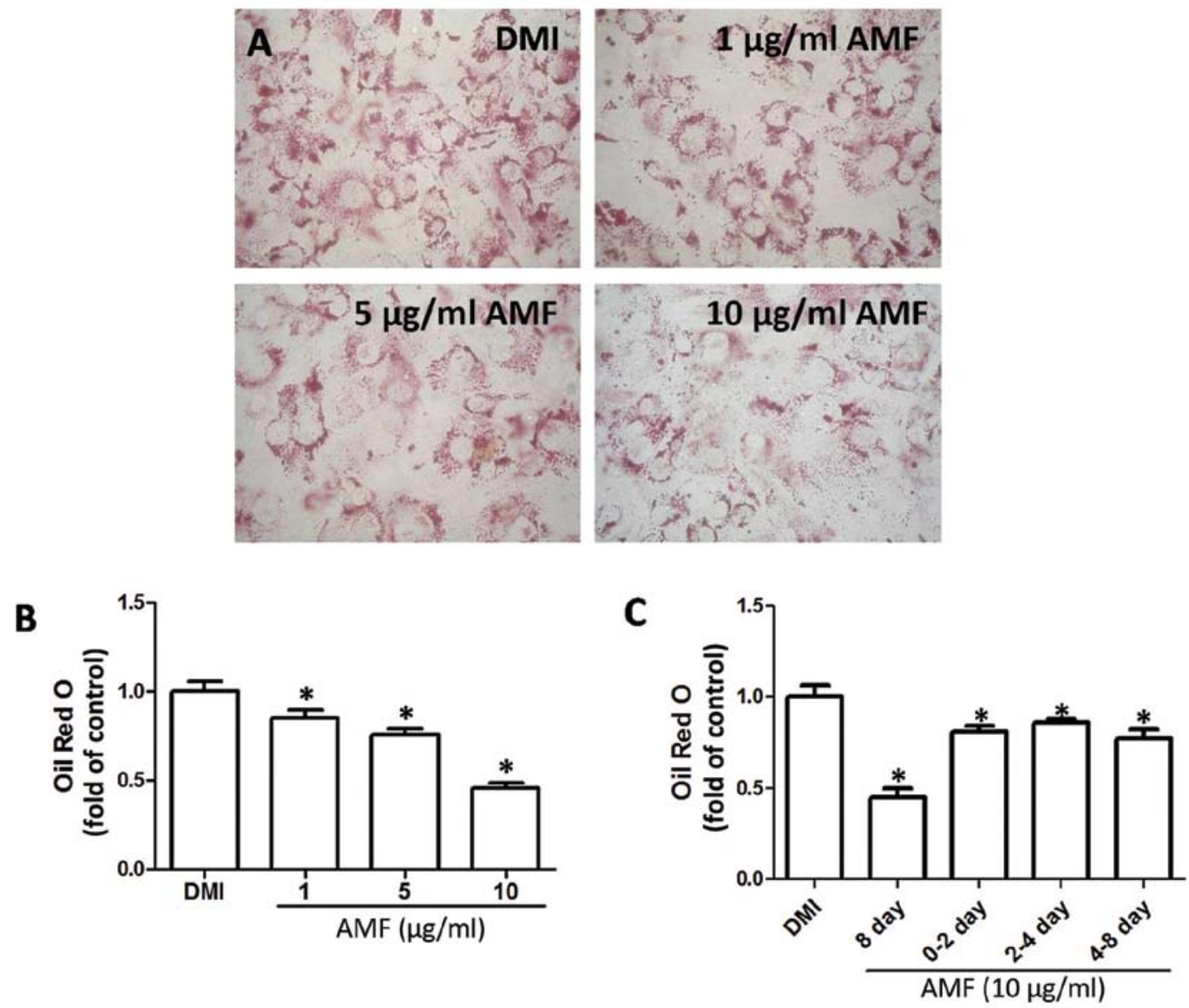

Figure 1. Effect of amentoflavone (AMF) on 3T3-L1 adipocyte differentiation. (A and B) 3T3-L1 pre-adipocytes were subjected to adipogenic differentiation in the presence of 1-10 $\mu \mathrm{g} / \mathrm{ml}$ AMF for 8 days. (A) After differentiation, lipid accumulation in adipocytes was examined by Oil Red O staining and observed under a microscope. (B) The oil droplets were then dissolved in isopropanol and the absorbance of the dyeetriglyceride complex was measured at $510 \mathrm{~nm}$. The results are expressed as folds of DMI. (C) 3T3-L1 pre-adipocytes were subjected to adipogenic differentiation for 8 days with $10 \mu \mathrm{g} / \mathrm{ml} \mathrm{AMF}$ at 0-8, 0-2, 2-4 or 4-8 days. After differentiation, lipid accumulation in adipocytes was examined by Oil Red O staining and then dissolved in isopropanol and the absorbance of the dyeetriglyceride complex was measured at $510 \mathrm{~nm}$. The results are expressed as folds of DMI. ${ }^{*}<<0.05$ compared with DMI.

cated that the administration of AMF significantly attenuated HF diet-induced lipid accumulation in rats.

AMF inhibits 3T3-L1 adipocyte differentiation. We examined the effects of AMF on 3T3-L1 adipocyte differentiation in vitro. AMF inhibited the accumulation of oil droplets in the differentiated adipocytes in a concentration-dependent manner, indicating that AMF suppressed 3T3-L1 adipocyte differentiation (Fig. 1A and B). Moreover, we evaluated the effect of AMF on 3T3-L1 adipocyte differentiation during different stages of differentiation. 3T3-L1 pre-adipocytes were subjected to adipogenic differentiation in the presence of $10 \mu \mathrm{g} / \mathrm{ml}$ AMF for 0-8, 0-2, 2-4 and 4-8 days. As shown in Fig. 1C, 0-2, 2-4 and 4-8 days of incubation of the cells with AMF significantly decreased Oil Red O staining in adipocytes, compared with the control, indicating that AMF exerted inhibitory effects on 3T3-L1 adipocyte differentiation at different stages of differentiation.

AMF inhibits MCE during 3T3-L1 adipocyte differentiation by promoting ROS generation. To examine the effects of AMF on MCE, 3T3-L1 pre-adipocytes were subjected to adipogenic differentiation in the presence of indicated concentrations of AMF for 2 days and cell viability and proliferation were detected. AMF inhibited cell viability and proliferation in a concentration-dependent manner at day 2 of differentiation, indicating the suppression of MCE (Fig. 2A and B). To examine the mechanisms resposible for the AMF-induced inhibition of MCE, the effect of AMF on C/EBP $\beta$ expression was determined. AMF inhibited the mRNA and protein expression of $\mathrm{C} / \mathrm{EBP} \beta$ in a concentration-dependent manner (Fig. $2 \mathrm{C}$ and D). Moreover, we examined the effect of AMF on ROS generation during MCE. As shown in Fig. 2E, at day 1 of differentiation, AMF markedly increased the ROS level in a concentrationdependent manner. Furthermore, AMF only increased the ROS level at the early stages of adipocyte differentiation, indicating that ROS generated by AMF mainly influence MCE (Fig. 2F). A shown in Fig. $2 \mathrm{G}$ and $\mathrm{H}$, we found that the antioxidant, NAC, significantly suppressed the inhibitory effect of AMF on cell proliferation and oil droplet accumulation, confirming that ROS generation was involved in the AMF-induced inhibition of adipocyte differentiation through the suppression of MCE.

AMF inhibits 3T3-L1 adipocyte differentiation through the inhibition of C/EBP $\alpha / P P A R \gamma$ signaling. To evaluate the mechanisms responsible for the inhibitory effect of AMF on the early and terminal differentiation of 3T3-L1 adipocytes, the effects 

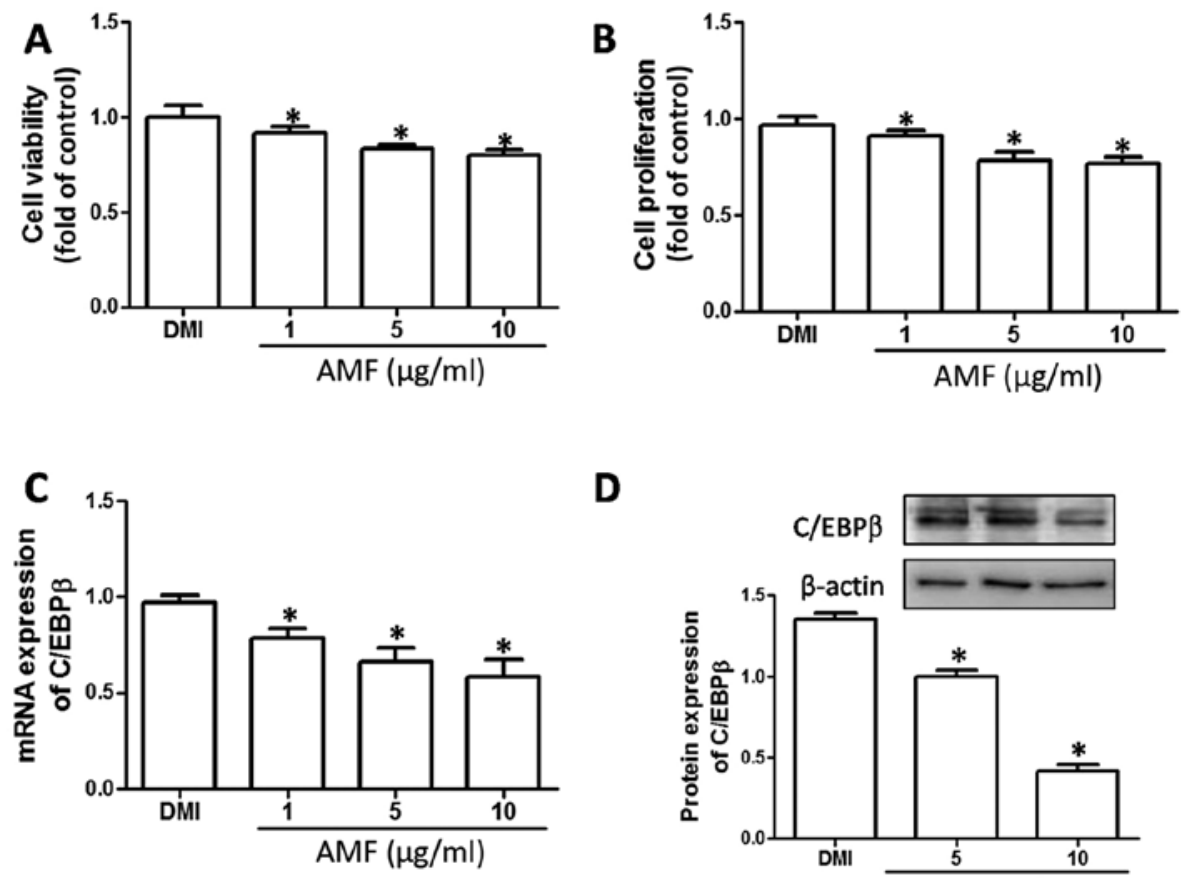

D
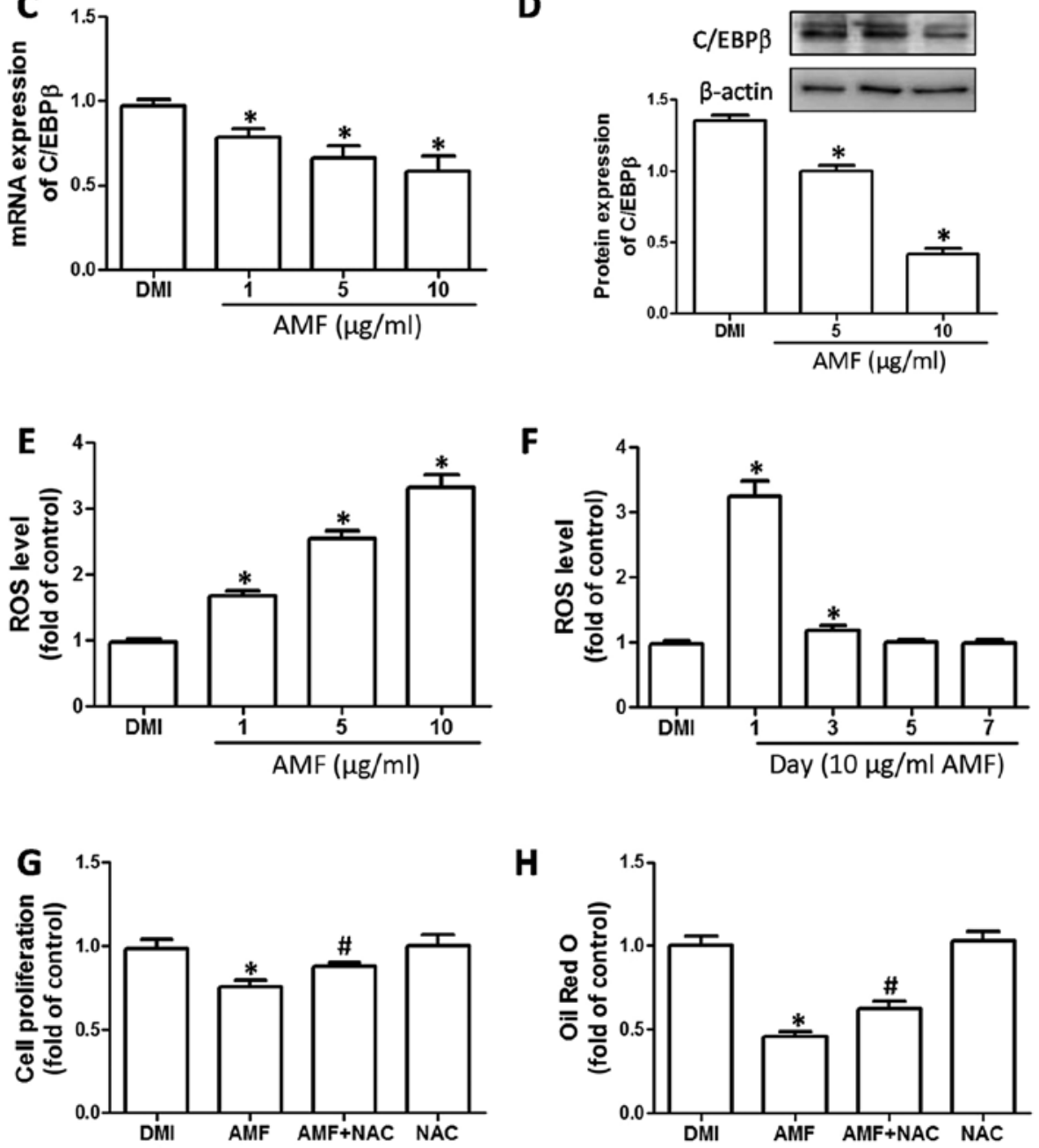

Figure 2. Effect of amentoflavone (AMF) on mitotic clonal expansion (MCE) during 3T3-L1 adipocyte differentiation. (A and B) 3T3-L1 pre-adipocytes were subjected to adipogenic differentiation in the presence of 1-10 $\mu \mathrm{g} / \mathrm{ml}$ AMF for 2 days. Subsequently, (A) cell viability and (B) cell proliferation were determined and the results are shown as folds of DMI. (C-E) 3T3-L1 pre-adipocytes were subjected to adipogenic differentiation in the presence of 1-10 $\mu \mathrm{g} / \mathrm{ml} \mathrm{AMF} \mathrm{for}$ $24 \mathrm{~h}$. Subsequently, the (C) mRNA and (D) protein expression of C/EBP $\beta$ was determined by RT-qPCR and western blot analysis, respectively. (E) Intracellular ROS levels were detected using the DCFH-DA probe and analyzed by flow cytometry. The results were shown as folds of DMI. (F) 3T3-L1 pre-adipocytes were subjected to adipogenic differentiation in the presence of $10 \mu \mathrm{g} / \mathrm{ml} \mathrm{AMF}$ for 1,3,5 and 7 days. Subsequently, intracellular ROS levels were determined and expressed as folds of increase compared to respective basal level at different differentiated stages. (G) 3T3-L1 pre-adipocytes were subjected to adipogenic differentiation in the presence of $10 \mu \mathrm{g} / \mathrm{ml}$ AMF with or without $100 \mu \mathrm{M} \mathrm{N}$-acetylcysteine (NAC) for 2 days. Subsequently, cell proliferation was determined and the results were shown as folds of DMI. (H) 3T3-L1 pre-adipocytes were subjected to adipogenic differentiation in the presence of $10 \mu \mathrm{g} / \mathrm{ml} \mathrm{AMF} \mathrm{with} \mathrm{or}$ without $100 \mu \mathrm{M} \mathrm{NAC}$ for 8 days. After differentiation, lipid accumulation in adipocytes was examined by Oil Red O staining and then dissolved in isopropanol and the absorbance of the dyeetriglyceride complex was measured at $510 \mathrm{~nm}$. The results are expressed as folds of DMI. "p $<0.05$ compared with DMI; ${ }^{p} \mathrm{p}<0.05$ compared with the AMF group.

of AMF on $\mathrm{C} / \mathrm{EBP} \alpha$ and PPAR $\gamma$ expression were determined. AMF inhibited the mRNA and protein expression of C/EBPa and PPAR $\gamma$ in a concentration-dependent manner (Fig. 3A-D).
Moreover, we detected the expression of aP2 and CD36, which are direct targets of PPAR $\gamma$ in the regulation of adipogenic differentiation. The mRNA expression of aP2 and CD36 was 

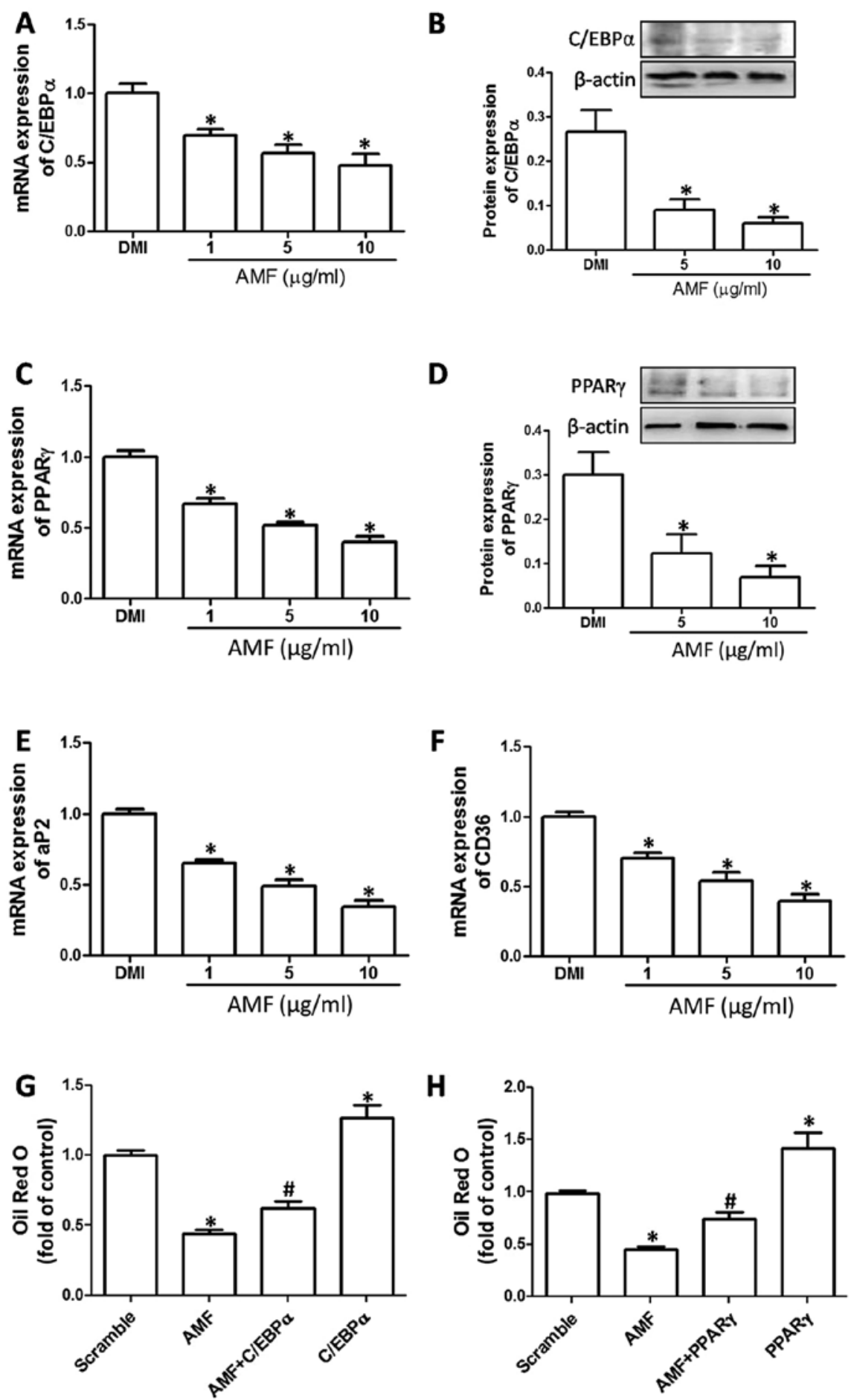

Figure 3. Effect of amentoflavone (AMF) on CCAAT/enhancer-binding protein $\alpha(\mathrm{C} / \mathrm{EBP} \alpha) /$ peroxisome proliferator-activated receptor $\gamma(\mathrm{PPAR} \gamma)$-regulated adipocyte differentiation of 3T3-L1 cells. (A-F) 3T3-L1 pre-adipocytes were subjected to adipogenic differentiation in the presence of 1-10 $\mu \mathrm{g} / \mathrm{ml} \mathrm{AMF}$ for 5 days. Subsequently, the (A and C) mRNA and (B and D) protein expression of C/EBP $\alpha$ and PPAR $\gamma$ was determined by RT-qPCR and western blot analysis, respectively. The mRNA expression of (E) aP2 and (F) CD36 was determined by RT-qPCR. (G and H) 3T3-L1 pre-adipocytes were transfected with C/EBPa or PPAR $\gamma$ plasmids 2 days before confluence. The cells were then subjected to adipogenic differentiation in the presence of $10 \mu \mathrm{g} / \mathrm{ml} \mathrm{AMF} \mathrm{for} 8$ days. After differentiation, lipid accumulation in adipocytes was examined by Oil Red $\mathrm{O}$ staining and then dissolved in isopropanol and the absorbance of the dyeetriglyceride complex was measured at $510 \mathrm{~nm}$. The results are expressed as folds of DMI. " $\mathrm{p}<0.05$ compared with DMI; ${ }^{*} \mathrm{p}<0.05$ compared with the AMF group.

significantly inhibited by AMF in a concentration-dependent manner (Fig. 3E and F). To further examine the role of the downregulation of C/EBP $\alpha$ and PPAR $\gamma$ in the AMF-induced inhibition of adipocyte differentiation, 3T3-L1 pre-adipocytes were transfected with $\mathrm{C} / \mathrm{EBP} \alpha$ and PPAR $\gamma$ plasmids. As shown in Fig. 2G and H, the overexpression of C/EBP $\alpha$ and PPAR $\gamma$ significantly prohibited the AMF-induced inhibition of adipocyte differentiation. These results indicated that AMF inhibited 3T3-L1 adipocyte differentiation through the inhibition of $\mathrm{C} / \mathrm{EBP} \alpha / \mathrm{PPAR} \gamma$ signaling. 


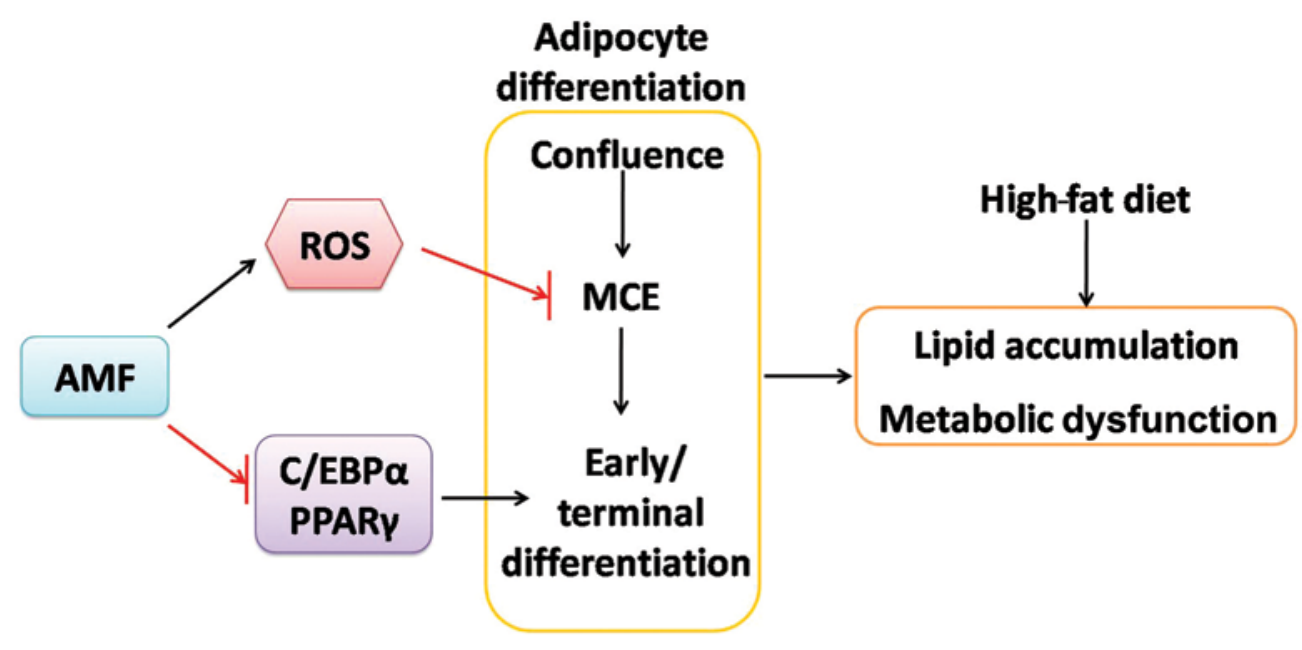

Figure 4. Schematic diagram of the molecular mechanisms underlying the amentoflavone (AMF)-induced protective effects against adipogenic differentiation and metabolic dysfunction.

\section{Discussion}

AMF is a polyphenolic compound derived from the extracts of Selaginella tamariscina. A number of studies have demonstrawted that AMF exerts anti-inflammatory (17-20), antioxidant (25-27), anti-viral $(28,29)$ and antitumor effects $(30,31)$, as well as protective effects against radiationinduced damaqge $(32,33)$ and neuroprotective effects $(32,33)$. $\mathrm{Na}$ et al found that AMF inhibited protein tyrosine phosphatase 1B activity, implicating a potential use of AMF in the treatment of type 2 diabetes and obesity (21). In the current study, we evaluated the protective effects of AMF against metabolic dysfunction and focused on the influence of AMF on adipocyte differentiation.

We found that AMF protected against HF diet-induced metabolic dysfunction in a dose-dependent manner, as evidenced by a decrease in fasting blood glucose levels, fasting insulin levels, HOMA-IR and a decrease in the level of glucose (as shown by IPGTT and IPITT). Lipid accumulation and thus, obesity is the major contributor to metabolic disroders induced by a HF diet $(34,35)$. In the present study, we focused on whether the improvement of metabolic function induced by AMF was attributed to the regulation of lipid accumulation. We found that AMF significantly inhibited the increase in body weights, the weights of perirenal adipose tissues and the serum TG content in a dose-dependent manner in rats fed a HF diet. Our data demonstrated that the inhibition of lipid accumulation may be involved in the inhibitory effects of AMF on HF dietinduced metabolic dysfunction.

We then examined the possible mechanism responsible for the AMF-induced inhibition of lipid accumulation. The accumulation of body fat largely depends on adipocyte differentiation. The course of adipocyte differentiation includes four steps, initial growth arrest, MCE, early differentiation and terminal differentiation, namely the development of the mature adipocyte phenotype $(5,6)$. Our results revealed that AMF inhibited the different stages of adipocyte differentiation. MCE is a synchronous process required for adipogenesis (36). C/ EBP $\beta$ is required for MCE during adipogenesis (12). We found that AMF decreased C/EBP $\beta$ expression in a concentrationdependent manner, leading to the inhibition of MCE. Moreover, our results indicated that ROS generation was involved in the AMF-induced inhibition of MCE. Hoever, it has been demonstrated that ROS enhance MCE and facilitate adipogenesis by promoting C/EBP $\beta$ expression (37). This discrepancy may be attributed to different levels or sources of ROS production. It has been demonstrated that AMF exhibits potential antioxidant activities (25-27). For example, Xu et al found the free radical scavenging and antielastase activities of AMF (26). Yamaguchi et al indicated that AMF from Brazilian pine Araucaria angustifolia exerted protective effects against DNA damage and lipoperoxidation (27). Combined with our results, it is suggested that AMF exerts differential effects on the redox state in different cell lines or under different conditions.

After MCE, early and terminal differentiation is mainly regulated by the PPAR $\gamma$ and $\mathrm{C} / \mathrm{EBP} \alpha$ interactive network. Without $\mathrm{C} / \mathrm{EBP} \alpha$, the formation of white adipose tissue is disrupted (38). The ectopic expression of $\mathrm{C} / \mathrm{EBP} \alpha$ promotes adipogenesis in various fibroblastic cell lines (39). However, $\mathrm{C} / \mathrm{EBP} \alpha$ is incapable of inducing adipogenesis without PPAR $\gamma$ (39). PPAR $\gamma$ regulates adipocyte differentiation by transcriptionally modulating a battery of target genes responsible for the terminal maturation of fat cells, including aP2 and CD36. Our results indicated that AMF inhibited PPAR $\gamma$ and $\mathrm{C} / \mathrm{EBP} \alpha$ expression and the expression of downstream targets in a concentration-dependent manner. The overexpression of PPAR $\gamma$ and $\mathrm{C} / \mathrm{EBP} \alpha$ suppressed the AMF-induced inhibition of the formation of oil droplets, indicating that the downregulation of PPAR $\gamma$ and C/EBP $\alpha$ was involved in the AMF-induced inhibitory effect on adipocyte differentiation.

In conclusion, in the present study, we found that AMF attenuated metabolic dysfunction in HF diet-fed rats and exerted inhibitory effects on 3T3-L1 adipocyte differentiation (Fig. 4). Furthermore, AMF promoted ROS generation, decreased $\mathrm{C} / \mathrm{EBP} \beta$, resulting in inhibition of MCE; on the other way, AMF inhibited PPAR $\gamma$ and C/EBP $\alpha$ expression, suppressed molecular pathways that responsible for the formation of lipid droplets, leading to inhibition of early and terminal 
differentiation (Fig. 4). The inhibitory effects on adipocyte differentiation may contribute to the protective effects of AMF against HF diet-induced metabolic dysfunction (Fig. 4). Overall, the data from the present study provide novel insight into the mechanisms underlying the protective effects of AMF against metabolic dysfunction and the inhibitory effects of AMF on adipocyte differentiation.

\section{References}

1. Wild S, Roglic G, Green A, Sicree R and King H: Global prevalence of diabetes: Estimates for the year 2000 and projections for 2030. Diabetes Care 27: 1047-1053, 2004.

2. American Diabetes Association: 6. Obesity management for the treatment of type 2 diabetes. Diabetes Care 39 (Suppl 1): S47-S51, 2016.

3. Tseng YH, Cypess AM and Kahn CR: Cellular bioenergetics as a target for obesity therapy. Nat Rev Drug Discov 9: 465-482, 2010

4. Wang $X$ and Hai C: Redox modulation of adipocyte differentiation: Hypothesis of 'Redox Chain' and novel insights into intervention of adipogenesis and obesity. Free Radic Biol Med 89: 99-125, 2015.

5. Rosen ED, Walkey CJ, Puigserver P and Spiegelman BM: Transcriptional regulation of adipogenesis. Genes Dev 14: 1293-1307, 2000.

6. Gregoire FM, Smas CM and Sul HS: Understanding adipocyte differentiation. Physiol Rev 78: 783-809, 1998.

7. Lefterova MI and Lazar MA: New developments in adipogenesis. Trends Endocrinol Metab 20: 107-114, 2009.

8. Tontonoz P and Spiegelman BM: Fat and beyond: The diverse biology of PPARgamma. Annu Rev Biochem 77: 289-312, 2008.

9. Tang QQ and Lane MD: Activation and centromeric localization of CCAAT/enhancer-binding proteins during the mitotic clonal expansion of adipocyte differentiation. Genes Dev 13: 2231-2241, 1999.

10. Yeh WC, Cao Z, Classon M and McKnight SL: Cascade regulation of terminal adipocyte differentiation by three members of the C/EBP family of leucine zipper proteins. Genes Dev 9: 168-181, 1995.

11. Tanaka T, Yoshida N, Kishimoto T and Akira S: Defective adipocyte differentiation in mice lacking the C/EBPbeta and/or C/EBPdelta gene. EMBO J 16: 7432-7443, 1997.

12. Tang QQ, Otto TC and Lane MD: CCAAT/enhancer-binding protein beta is required for mitotic clonal expansion during adipogenesis. Proc Natl Acad Sci USA 100: 850-855, 2003.

13. Clarke SL, Robinson CE and Gimble JM: CAAT/enhancer binding proteins directly modulate transcription from the peroxisome proliferator-activated receptor gamma 2 promoter. Biochem Biophys Res Commun 240: 99-103, 1997.

14. Wu Z, Rosen ED, Brun R, Hauser S, Adelmant G, Troy AE, McKeon C, Darlington GJ and Spiegelman BM: Cross-regulation of C/EBP alpha and PPAR gamma controls the transcriptional pathway of adipogenesis and insulin sensitivity. Mol Cell 3: 151-158, 1999.

15. Shao D and Lazar MA: Peroxisome proliferator activated receptor gamma, CCAAT/enhancer-binding protein alpha, and cell cycle status regulate the commitment to adipocyte differentiation. J Biol Chem 272: 21473-21478, 1997.

16. Evans RM, Barish GD and Wang YX: PPARs and the complex journey to obesity. Nat Med 10: 355-361, 2004.

17. Huang N, Rizshsky L, Hauck CC, Nikolau BJ, Murphy PA and Birt DF: The inhibition of lipopolysaccharide-induced macrophage inflammation by 4 compounds in Hypericum perforatum extract is partially dependent on the activation of SOCS3. Phytochemistry 76: 106-116, 2012.

18. Tsai SC, Liang YH, Chiang JH, Liu FC, Lin WH, Chang SJ, Lin WY, Wu CH and Weng JR: Anti-inflammatory effects of Calophyllum inophyllum L. in RAW264.7 cells. Oncol Rep 28: 1096-1102, 2012.

19. Woo ER, Lee JY, Cho IJ, Kim SG and Kang KW: Amentoflavone inhibits the induction of nitric oxide synthase by inhibiting NF-kappaB activation in macrophages. Pharmacol Res 51: 539-546, 2005.

20. Banerjee T, Valacchi G, Ziboh VA and van der Vliet A: Inhibition of TNFalpha-induced cyclooxygenase- 2 expression by amentoflavone through suppression of NF-kappaB activation in A549 cells. Mol Cell Biochem 238: 105-110, 2002.
21. Na M, Kim KA, Oh H, Kim BY, Oh WK and Ahn JS: Protein tyrosine phosphatase $1 \mathrm{~B}$ inhibitory activity of amentoflavone and its cellular effect on tyrosine phosphorylation of insulin receptors. Biol Pharm Bull 30: 379-381, 2007.

22. Wang $\mathrm{X}, \mathrm{Gu} \mathrm{C}, \mathrm{He} \mathrm{W}$, Ye X, Chen $\mathrm{H}$, Zhang $\mathrm{X}$ and Hai C: Glucose oxidase induces insulin resistance via influencing multiple targets in vitro and in vivo: The central role of oxidative stress. Biochimie 94: 1705-1717, 2012

23. Li Q, Peng H, Fan H, Zou X, Liu Q, Zhang Y, Xu H, Chu Y, Wang C, Ayyanathan K, et al: The LIM protein Ajuba promotes adipogenesis by enhancing PPARgamma and p300/CBP interaction. Cell Death Differ 23: 158-168, 2016.

24. Hou X, Tong Q, Wang W, Xiong W, Shi C and Fang J: Dihydromyricetin protects endothelial cells from hydrogen peroxide-induced oxidative stress damage by regulating mitochondrial pathways. Life Sci 130: 38-46, 2015

25. Erdogan-Orhan I, Altun ML, Sever-Yilmaz B and Saltan G: Anti-acetylcholinesterase and antioxidant assets of the major components (salicin, amentoflavone, and chlorogenic acid) and the extracts of Viburnum opulus and Viburnum lantana and their total phenol and flavonoid contents. J Med Food 14: 434-440, 2011.

26. Xu GH, Ryoo IJ, Kim YH, Choo SJ and Yoo ID: Free radical scavenging and antielastase activities of flavonoids from the fruits of Thuja orientalis. Arch Pharm Res 32: 275-282, 2009.

27. Yamaguchi LF, Vassão DG, Kato MJ and Di Mascio P: Biflavonoids from Brazilian pine Araucaria angustifolia as potentials protective agents against DNA damage and lipoperoxidation. Phytochemistry 66: 2238-2247, 2005

28. Coulerie P, Nour M, Maciuk A, Eydoux C, Guillemot JC, Lebouvier N, Hnawia E, Leblanc K, Lewin G, Canard B, et al: Structure-activity relationship study of biflavonoids on the Dengue virus polymerase DENV-NS5 RdRp. Planta Med 79: 1313-1318, 2013.

29. Ma SC, But PP, Ooi VE, He YH, Lee SH, Lee SF and Lin RC: Antiviral amentoflavone from Selaginella sinensis. Biol Pharm Bull 24: 311-312, 2001.

30. Lee S, Kim H, Kang JW, Kim JH, Lee DH, Kim MS, Yang Y, Woo ER, Kim YM, Hong J and Yoon DY: The biflavonoid amentoflavone induces apoptosis via suppressing E7 expression, cell cycle arrest at sub- $\mathrm{G}_{1}$ phase, and mitochondria-emanated intrinsic pathways in human cervical cancer cells. J Med Food 14: 808-816, 2011.

31. Siveen KS and Kuttan G: Effect of amentoflavone, a phenolic component from Biophytum sensitivum, on cell cycling and apoptosis of B16F-10 melanoma cells. J Environ Pathol Toxicol Oncol 30: 301-309, 2011.

32. Lee CW, Na Y, Park NH, Kim HS, Ahn SM, Kim JW, Kim HK and Jang YP: Amentoflavone inhibits UVB-induced matrix metalloproteinase-1 expression through the modulation of AP-1 components in normal human fibroblasts. Appl Biochem Biotechnol 166: 1137-1147, 2012.

33. Park NH, Lee CW, Bae JH and Na YJ: Protective effects of amentoflavone on Lamin A-dependent UVB-induced nuclear aberration in normal human fibroblasts. Bioorg Med Chem Lett 21: 6482-6484, 2011.

34. Jo YH, Choi KM, Liu Q, Kim SB, Ji HJ, Kim M, Shin SK, Do SG, Shin E, Jung G, et al: Anti-obesity effect of 6,8-diprenylgenistein, an isoflavonoid of Cudrania tricuspidata fruits in high-fat dietinduced obese mice. Nutrients 7: 10480-10490, 2015.

35. de Oliveira PR, da Costa CA, de Bem GF, Cordeiro VS, Santos IB, de Carvalho LC, da Conceição EP, Lisboa PC, Ognibene DT, Sousa PJ, et al: Euterpe oleracea Mart.-derived polyphenols protect mice from diet-induced obesity and fatty liver by regulating hepatic lipogenesis and cholesterol excretion. PLoS One 10: e0143721, 2015.

36. Tang QQ, Otto TC and Lane MD: Mitotic clonal expansion: A synchronous process required for adipogenesis. Proc Natl Acad Sci USA 100: 44-49, 2003.

37. Lee H, Lee YJ, Choi H, Ko EH and Kim JW: Reactive oxygen species facilitate adipocyte differentiation by accelerating mitotic clonal expansion. J Biol Chem 284: 10601-10609, 2009.

38. Linhart HG, Ishimura-Oka K, DeMayo F, Kibe T, Repka D, Poindexter B, Bick RJ and Darlington GJ: C/EBPalpha is required for differentiation of white, but not brown, adipose tissue. Proc Natl Acad Sci USA 98: 12532-12537, 2001.

39. Freytag SO, Paielli DL and Gilbert JD: Ectopic expression of the CCAAT/enhancer-binding protein alpha promotes the adipogenic program in a variety of mouse fibroblastic cells. Genes Dev 8: 1654-1663, 1994. 